\title{
Think tanks and strategic policy-making: the contribution of think tanks to policy advisory systems
}

\author{
Bert Fraussen $^{1} \cdot$ Darren Halpin ${ }^{1}$
}

(C) Springer Science+Business Media New York 2016

\begin{abstract}
Think tanks have proliferated in most Western democracies over the past three decades and are often considered to be increasingly important actors in public policy. Still, their precise contribution to public policy remains contested. This paper takes the existing literature in a new direction by focusing on the capacity of think tanks to contribute to strategic policy-making and assessing their particular role within policy advisory systems. We propose that strategic policy-making capacity requires three critical features: high levels of research capacity, substantial organizational autonomy and a long-term policy horizon. Subsequently, we assess the potential of think tanks to play this particular role in policy-making, using empirical evidence from structured interviews with a set of prominent Australian think tanks.
\end{abstract}

Keywords Think tanks - Strategic policy-making · Policy advisory systems · Policy advice · Policy capacity

\section{Introduction}

There is concern that modern political processes operate bereft of moments where new ideas or fresh approaches are developed and considered for political action. Too often, one sees crisis-driven responses with little apparent thought to long-term considerations or strategic objectives. Previous research has described policy-making processes as characterized by long periods of stability and delay, followed by short periods of overreaction and dramatic change (e.g. Baumgartner et al. 1993; Jones and Baumgartner 2005) Others focus on the crisis-driven nature of political work and the implications this has for policy success (see McConnell 2008). More often still, there is a sense that highly important long-term

Bert Fraussen

Bert.Fraussen@anu.edu.au

1 Research School of Social Sciences, Australian National University, Canberra, ACT, Australia 
questions are pushed to one side in preference to the small set of issues high on the current agendas of political elites. Research consistently finds that the issues given a high priority by government are those that are viewed as immediately critical by public opinion (e.g. Burstein 2003; for similar findings on the linkage between lobbying activity and public opinion, see Rasmussen et al. 2013). While the responsiveness of political elites to public opinion might be viewed as evidence of political linkage - and hence highly positivethere is nevertheless the question as to whether the long-term strategic issues are being tackled.

The literature around strategic policy-making seeks to problematize this particular question (see Marsh 1995). It suggests that every political system needs the ability to engage in policy conversations and learning that will foster solutions to those policy problems that are critical to society (see discussion in Yankelovich 1991; Marsh and Miller 2012). It is argued that in contemporary Western democracies existing political institutions do not often encourage these discussions and in fact foster disincentives for engaging in strategic policy debates. More generally, governance arrangements, and the way in which interactions between policymakers and other societal actors are structured, can constrain the capacity of governments to identify and address key policy problems and lead to the persistence of policy failures (Howlett et al. 2015: 210). This lack of capacity may be most apparent with respect to major systemic issues, such as social inequality or climate change, as governance success in these areas requires "more than simply hitting a narrow target and may require more comprehensive consideration within and across policy domains" (Peters 2015: 263). Compared to economic markets, processes of learning and competition are considered less effective in politics, where both short time horizons and the strong status quo bias of existing institutions reinforce path-dependent patterns. As a result, "in many cases, the long term is essentially beyond the political horizon", while established institutions and programs often tend to be "sticky" or enduring (Pierson 2004: 42). There is a small but persuasive literature that ponders ways in which space might be found for consideration of the big challenges outside of arenas that are highly politicized and driven by electoral concerns. For some, the focus is on amending existing political institutionssuch as legislative committees or state research capacity-to create a space for fresh and new ideas to be rehearsed (for example, see Drutman 2015; Halpin et al. 2012; Marsh 1995). An alternative view puts more emphasis on the strategic policy capacity of actors and organizations outside of the formal political system, such as academic experts, foundations, advocacy groups, non-profits and research organizations (e.g. Peters 2015). As these external non-governmental organizations proliferated and became more engaged in advocacy, the number of potential sources of policy expertise and information has increased considerably (May et al. 2014). While this more plural, horizontal advice-giving landscape might carry important implications for policy processes, our knowledge of the precise contribution of these external actors has remained rather limited.

In this article, we focus our attention on one type of non-governmental organization which the literature suggests is particularly well placed to contribute to strategic policymaking, namely think tanks (Craft and Howlett 2012). Following Rich (2004), we define think tanks as "independent, non-interest based, non-profit organizations that produce and principally rely on expertise and ideas to obtain support and influence the policy-making process". Taking these organizations as our empirical focus, we aim to connect the discussion about the need for strategic policy capacity in democratic systems with an assessment of the policy capabilities that characterize think tanks. At the same time, we make a new contribution to the literature on think tanks by focusing more specifically on their role and potential within the broader context of policy advisory systems. More 
specifically, we probe the capacity of think tanks to provide strategic policy advice and link this potential to particular organizational features. That is, we assume that to provide this type of advice, certain organizational features and practices are critical, most importantly a high investment in research capacity, a reasonable of level of organizational autonomy and a long-term horizon. By relating our findings to previous work on policy advisory systems, and comparing the policy capacity of think tanks with that of other key political actors, notably interest groups, we aim to advance our understanding of the political niche that they occupy. In so doing, our study sets out to speak to work that considers the role of think tanks within the broader field of "research organizations", such as work on "knowledge regimes" (Campbell and Pedersen 2014) and "policy regime perspectives" (May and Jochim 2013). ${ }^{1}$

The next section of this article addresses in more detail the potential of think tanks to contribute to strategic policy-making and highlights their potential role in policy advisory systems (including the particular type of advice they can provide). We then introduce the empirical context for our work from the Australian think tank system. More specifically, our analyses are based on structured telephone interviews with 21 Australian think tanks, in which we assessed their capacity to contribute to strategic policy-making by analysing their research capacity, organizational autonomy and long-term orientation. In the last sections of this article, we provide a synthesis of our key findings and address how they relate to recent work on policy advisory systems, and prospects for strategic policy-making.

\section{The contribution of think tanks to strategic policy-making and their role in policy advisory systems}

Strategic policy-making typically requires actions that are part of a more integrative approach and seek to suspend short-term political imperatives in favour of long-term policy goals. Gaining traction on the big policy challenges of our time-such as climate change, energy and migration-requires political institutions that can harness the momentum of the policy cycle (and public opinion), yet at the same time allow long-term, cross-sectoral thinking to prevail (see discussion in Marsh 1995). While these objectives often receive vocal support from policymakers, they prove hard to achieve in practice, as short-term horizons and narrow issue-mindsets tend to dominate. For instance, a recent study of policy-making horizons within the Dutch public service, reports that "...policy makers think that both time-horizons matter, but in the turbulence of every-day processes the shorter time-horizons tend to dominate attention over the long term" (van der Steen and van Twist 2013: 38).

How can political systems develop a higher capacity for strategic policy-making? For some, raw participation is the answer. Democratic deficits and other diagnoses suggest that the elite or technocratic nature of policy is undermining and confounding attempts to generate a civil society consensus (see della Porta 2013). But, weakening iron triangles or policy communities in favour of citizen-wide consultations, or other forms of local

\footnotetext{
${ }^{1}$ In the latter case, a regime is defined as a "governing arrangement for addressing policy problems" that consists of institutional arrangements, ideas and interests (May and Jochim 2013: 428). Our concern here is mainly with the latter component. Next to institutional arrangements and ideas, interests also play a crucial role in shaping the legitimacy, coherence and durability of policy regimes. These interests can relate to advocacy organizations, yet also research organizations such as think tanks. Not only do these interests represent constituencies that can provide support or opposition to policymakers, they are also expected to shape the governing capacity of a regime.
} 
deliberation, is not an obvious panacea (Jordan 2007). For one, expression of citizen views is desirable, but what about the policy content and trade-offs? What about the accountability and authorization of "representatives"? In this regard, Jordan and Greenan, for instance, argue that "current conventional political science builds up expectations that individual citizens in deliberative local forums can have meaningful influence, yet wants to downplay and disregard interventions by organizations with membership numbers, professional research skills, and policy expertise. This is the triumph of hope over reason" (2012: 72).

A more convincing approach is to look for ways to improve existing political institutional arrangements. The problem, however, is that strategic policy-making capacity within the state is being eroded. The hollowing out of state capacity-through the slimming down and shifting emphasis of public administration staff (i.e. outsourcing and commissioning to third parties, rather than internal production of policy evidence and advice, e.g. Milward and Provan 2000) - raises the question as to where this capacity for long-term integrative thinking has been displaced. Specifically, it shifts our attention to the possible role of external actors in policy-making and, more generally, to policy advisory systems (for a detailed review of this literature, see Craft and Howlett 2012). Here, policy advisory systems are defined as "an interlocking set of actors, with a unique configuration in each sector and jurisdiction who provided information, knowledge and recommendations for action to policymakers" (Craft and Howlett 2012: 80, see also Halligan 1995). To characterize these systems of policy advice, researchers have often used the traditional insideroutsider distinction, which emphasizes the locational position of actors that may contribute to public policy and indicates whether they are located internal or external to government (e.g. Maloney et al. 1994; Marsh et al. 2009). In this regard, one could distinguish (advisory) policy units inside government from parliamentary committees and policy input provided by advocacy groups. Furthermore, to classify the particular content of the formulated advice, a classic typology involved the distinction between partisan-ideological "political" and administrative or "technical" advice (see also Bouwen 2002).

More recently, these locational models of policy advisory systems, as well as the dimensions of policy content, have been revised to account for shifts in modes of governance, in particular the advent of a more plural and horizontal advice-giving landscape in which the government bureaucracy (or public service) plays a less central and dominant role (Craft and Wilder 2015; Hill and Lynn 2005). Craft and Howlett, for instance, developed a typology of policy advisory systems characterized by policy content, in which they distinguished two dimensions: procedural versus substantive and short-term reactive versus long-term anticipatory (2012: 90-91). Following these distinctions, they emphasize four types of advice: "pure political and policy process advice" (short-term reactive and procedural), "short-term crisis and fire-fighting advice" (short-term reactive and substantive), "medium to long-term policy steering advice" (long-term anticipatory and procedural) and "evidence-based policy-making" (long-term anticipatory and substantive). While they emphasize that neither partisan nor civil society actors have a monopoly on one type of advice, they do formulate expectations regarding the type of advice different organizations are most likely to provide. For instance, they suggest that interest groups and lobbyists are best suited to deliver procedural advice of a short-term, reactive nature, while think tanks and academic advisers are associated with substantive and long-term, anticipatory policy advice.

While their precise proposition needs empirical testing, it is this kind of connection between organizational form and policy advice that is our focal point in this article. Specifically, we focus on the potential contribution of think tanks, as a class of political 
organization, to strategic policy-making. Researchers generally agree that think tanks have become an important component of the political landscape in a wide range of countries and that their growth in numbers has accelerated considerably (McGann 2015; Stone 2000). While comparative research in this area is rather limited (but see Campbell and Pedersen 2014; Pautz 2010; Stone and Denham 2004), it suggests that while think tanks were initially most prominent in Anglo-Saxon, pluralist countries, they are also becoming quite central actors in typical neo-corporatist countries, such as Germany. While there is considerable disagreement as to their defining features, their political relevance seems much less contested. Research in various countries has shown that think tanks are not only quite prominent in the media, where they provide op-eds or function as expert commentators, but are also frequently active in government consultations (Abelson 2002; Rich and Weaver 1998). For instance, Grossman finds that, compared to advocacy groups, think tanks are not only significantly more present in the news, but also more regularly involved in policymaking, as they testify to the US Congress four times as often (2012). These findings resonate with arguments that political parties increasingly look towards these actors for policy input and ideas (e.g. Pautz 2010, 2013). In this regard, Stone argues that think tanks "are not simply informants in transmitting research policy", but "help provide the conceptual language, the ruling paradigms, the empirical examples, that then become the accepted assumptions for those making policy" (2007: 276).

We aim to build on this line of work here, by focusing more specifically on the particular role of think tanks within the broader context of policy advisory systems, and linking their potential capacity to provide strategic policy advice to particular organizational properties. That is, we assume that to provide this type of strategic advice, certain organizational features and practices are critical, most importantly a high investment in research capacity, a reasonable of level of organizational autonomy and a long-term time horizon. By relating our findings to previous work on policy advisory systems, and comparing the policy capacity of think tanks with that of other key political actors, notably interest groups, we aim to advance our understanding of the political niche that they occupy.

\section{Scope and method}

In our study, we examine the propositions outlined above through a systematic exploration of the Australian case. We included all Australian organizations that are consistent with the definition of think tank outlined above. This implies that we excluded interest-based research organizations (which we conceive as interest groups) and also omitted research organizations that are considered part of government, or linked to universities or private corporations. To our knowledge, previous work has not yet identified a complete overview of all think tanks active in Australia. In order to establish a research population, we used multiple sources. First, we conducted a media search on Factiva, using "think tank" as search term, consulting five key national media outlets (The Age, The Australian, The Australian Financial Review, The Canberra Times and The Sydney Morning Herald) for reports on think tanks in the past 2 years. ${ }^{2}$ These results were cross-checked against mentions of Australian think tanks in key scholarly works (most importantly Marsh and Stone 2004; "t Hart and Vromen 2008) and online resources. Table 5 in the "Appendix" includes an overview of all the think tanks that we could identify, as well as their year of

\footnotetext{
2 This search was conducted on 17 November 2014
} 
establishment. In earlier work Marsh (1994) and Marsh and Stone (2004), noted a remarkable proliferation of think tanks in Australia. This trend only seems to have intensified. ${ }^{3}$ Of the 59 think tanks we identified, almost $70 \%$ were established since 2000 (the average think tank in our set of 59 organizations is very young, average age $=18$, median age $=11$ ). We contacted 30 think tanks to request an interview. The selection was guided by the desire to capture organizations that vary with respect to prominence, although we prioritized the inclusion of highly prominent think tanks over those with very few or no media appearances. Of this set, 21 think tanks (70\%) agreed to participate in our study and completed a structured telephone interview. These interviews were generally conducted with the CEO or Director of these organizations. The survey covered key themes such as how think tanks organize in order to acquire policy expertise and the activities they engage into shape policy and public debate. While the majority of the questions in the survey were close-ended, we also included a limited number of open questions, related to how respondents described the essential features and distinct nature of a think tank, as well as the mission of their organization and their linkages to other organizations. ${ }^{4}$

The development of think tanks in Australia has been described in terms of "waves", which often echoed or followed developments in the think tank scene in the UK (see Marsh and Stone 2004 for more background). In this view, a first wave includes think tanks that were established before or just after World War II, of which only a few organizations are still active today: the Australia Institute of Policy and Science (AIPS 1932), the Institute for Public Affairs (IPA 1943), the Australian Institute for International Affairs (AIIA 1924), the Committee for the Economic Development of Australia (CEDA 1960) and the Australian Fabian Society (1947). Most of these think tanks had a very generalist orientation (though politically right of centre), focusing on international affairs, public policy, economy or progressive issues. A "second wave" of "New Right" think tanks emerged from the mid-1970s (Marsh and Stone 2004: 248). Some examples here include the Centre for Independent Studies (CIS 1976), the HR Nicholls Society (1986), the Australia Institute of Public Policy (AIPP, which later merged with IPA), the Sydney Institute (1989, which originated from the New South Wales branch of the IPA) and the Tasman Institute (which evolved into a private commercial consultancy firm in 1998). The emergence and proliferation of these more right-of-centre organizations provoked a counter mobilization of centre-left organizations (a third wave), such as the Evatt Foundation (1979), WETtank (1992) and the Australia Institute (1994), which was followed by the establishment of a more diverse set of think tanks in the late 1990s and 2000s. Think tanks established more recently consist of a mix of generalist organizations (often focused on public policy or international affairs), but also include some more specialized think tanks that concentrate on particular topics, such as environment, education, defence or regional Australia (our analysis below includes a more detailed discussion of their policy agenda). In the last two decades, some prominent think tanks have also been established by the government. Some of these are party think tanks, such as Menzies Research Centre (1994) and Chifley Research Centre (2000), respectively, affiliated to the Liberal Party and Australian Labour

\footnotetext{
3 An alternative explanation would be that there is high turnover among think tanks, with only a few of them surviving over time. While we do not have historical data on think tank foundings and disbandings, the proliferation hypothesis seems in line with findings on think tank establishment in other countries (e.g. Rich 2001: 585).

4 The set of questions was inspired by earlier research on think tanks (e.g. Fraussen et al. 2016), as well as previous survey research on interest groups (Walker 1991; Gray and Lowery 1996; Schlozman and Tierney 1986).
} 
Party. Furthermore, a think tank focused on international affairs, the Australian Strategic Policy Institute, was also established by the government in order to provide expertise on issues related to foreign policy.

\section{Assessing the contribution of think tanks to strategic policy-making}

Having clarified our definition of a think tank and provided more background on the Australian think tank landscape, the remainder of this article focuses on the potential for think tanks to contribute to strategic policy-making and their possible role in policy advisory systems. While the prevailing focus on think tanks tends to question the value these organizations can bring to public policy, our approach emphasizes those dimensions that (could) make this type of political organization uniquely positioned as a vehicle to support strategic policy-making. In this regard, three organizational features are considered valuable features:

- a strong focus on building research capacity and maintaining intellectual credibility

- a considerable level of organizational autonomy, including the ability to move quickly from one issue to another, without facing too many internal or external organizational constraints on decision-making processes and issue prioritization

- a proactive stance with a focus on future challenges

In what follows, we clarify these dimensions in greater detail and provide an empirical assessment of their manifestation, relying on the results of our survey of Australian think tanks. Additionally, where relevant, we also address the extent to which the presence of these organizational features can be linked to particular types of advice, thus also clarifying the role these organizations can play in the context of policy advisory systems.

\section{Intellectual credibility and research capacity}

If nothing else, scholars can certainly agree that some kind of research activity is a necessary, but not sufficient, condition to be considered a think tank. These organizations are assumed to have considerable research capacity, which enables them to develop and promote new policy ideas based on scientific evidence and expertise. Yet, much work has questioned the extent to which think tanks actually prioritize research and have the capacity to produce policy expertise (Rich 2004; Stone 2007). Here, we measure the research-driven nature of these organizations by considering the importance of research vis-à-vis other organizational objectives, as well as evaluate the extent to which a commitment to high-quality research is reflected in the allocation of organizational resources.

Political organizations, such as interest groups, political parties and think tanks, often have multiple organizational objectives (for a detailed discussion, see Berkhout 2013). For instance, interest groups need to balance the logic of membership and the logic of influence (Schmitter and Streeck 1999). They permanently make trade-offs between a focus on membership demands and the provision of services to their constituency versus investments in their appeal to policymakers, for instance by providing policy-relevant expertise, the capacity to implement policy programs or the ability to ensure approval from a particular constituency (Maloney et al. 1994; Halpin 2014, chapter 10). While think tanks are likely to face fewer organizational constraints given their non-representative nature (a topic to which we return below), they too have to balance different organizational objectives. In 
Table 1 Relative importance of organizational objectives $(n=20)$

\begin{tabular}{lll}
\hline & $\begin{array}{l}\text { Most important (think tanks } \\
\text { selecting objective as number 1) } \\
(\%)\end{array}$ & $\begin{array}{c}\text { Average rank } \\
(1=\text { most } \\
\text { important; } \\
5=\text { least important) }\end{array}$ \\
\hline $\begin{array}{l}\text { Reputation for intellectual quality and } \\
\text { integrity }\end{array}$ & 50 & 2.1 \\
Ability to influence specific policy outcomes & 35 & 2.2 \\
Frequent access to policymakers & 10 & 3.6 \\
Ability to set the policy agenda & 5 & 2.9 \\
High level of media visibility & 0 & 4.2 \\
\hline
\end{tabular}

our survey, we asked think tanks to rank five objectives according to their relative importance to their organization. The results in Table 1 appear to confirm the researchdriven nature of these organizations, as 10 out of 20 think tanks ranked "a reputation for intellectual quality and integrity" as their most important objective. ${ }^{5}$

The centrality of a reputation for intellectual quality and integrity is in line with earlier research identifying this as a key success factor ("t Hart and Vromen 2008: 137), and partly resonates with the idea that think tanks "maximize public credibility and political access to make their expertise and ideas influential in policy-making" (Rich 2004). It also echoes arguments that policy experts care deeply about upholding professional norms and making sure their work is above reproach (e.g. Campbell and Pedersen 2014: 224-225). While the think tanks in the survey strongly focus on credibility and policy influence (which has a similar average ranking, but was identified as most important by only seven think tanks), it seems that access to policymakers and (especially) high levels of media visibility are considered relatively less important. These findings suggest that assessments of activities of think tank would benefit from a broader view on think tank "success" and the type of policy work that they engage in (see also Fraussen et al. 2016). For instance, some of these organizations might mainly seek attention from a more elite and narrow audience (such as specialist academics or particular policymakers). In that sense, they would resemble a first generation of think tanks, who Stone has described as "low-profile actors seeking to inform policy in a detached nonpartisan scholarly fashion", who are "not overtly seeking media attention" nor are "highly visible actors in policy debate" (2000: 150).

This finding contradicts much previous research on think tanks, which has often emphasized their public-facing role, arguing that think tanks are quite successful in gaining political prominence through appearances in the media, for instance through providing comments or serving as columnists (Marsh and Stone 2004; Rich and Weaver 1998; Smith 2000). Yet, this observation only seems accurate for a small minority of the think tanks. In Fig. 1, we assess the prominence of all the identified think tanks in the news over a period of 2 years by considering their mentions in five national Australian newspapers (Australian Financial Review, The Australian, The Age, The Sydney Morning Herald and The Canberra Times). We observe variations in prominence among the population of organizations at hand, and utilize a natural cut-point — at around 100 mentions — as a benchmark for high levels of prominence. While nine of the 59 think tanks we identified appeared in the print

${ }^{5}$ One think tank opted not to complete this question. 
Fig. 1 Media mentions of think tanks $(n=59 ; 17 / 11 / 2012-17 /$ $11 / 2014)$

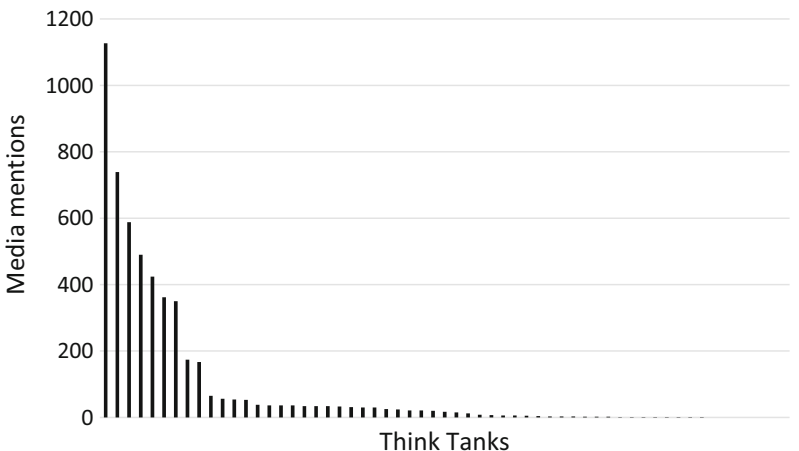

media more than 100 times over this period, about half of them only show up in the media very occasionally (less than ten times over this period), or are not mentioned at all. ${ }^{6}$ While the nine think tanks that are highly prominent vary considerably in terms of age (range 7-72 years; median 21), they represent some of the more well-established organizations, with annual revenues varying from 2.6 to 6.5 million AUD (Vromen and Hurley 2015: 172). More important in the context of our framework, however, is that five of them have a rather generalist policy orientation (they identify themselves as a "public policy" think tank or emphasize multiple policy domain interests in their mission). This aligns with previous findings by Rich in the US context, where he observed that "full service" think tanks, which span multiple policy domains, were more likely to receive attention from journalists and policymakers, to whom they represent "convenient resources on a variety of issues" (2001: 587).

Obviously, there is a difference between claiming that a reputation for intellectual quality and integrity is a prime organizational objective, and investing in the organizational capacity to produce high-quality policy-relevant output. That is, the production and accumulation of expertise generally requires considerable resources, both financially and in terms of personnel. When Marsh and Stone (2004) evaluated the capacity of think tanks in Australia, however, they described them as small organizations with limited financial resources. While we do not have figures on the budgets of the organizations included in our survey, we do have information on the number of staff (measured as full-time equivalents), which is considered a reasonable proxy of an organization's financial base. Our results largely confirm these earlier observations, as the median number of staff employed by the think tanks we surveyed is three (average 6.2; range 0-30). While there are think tanks that employ more than ten FTEs, in some cases even 27 or 30, these think tanks (which generally also enjoy higher levels of media prominence) really are the exception rather than the rule. Furthermore, only five of the think tanks indicated that all their staff are paid employees, while 11 of them rely on a mix of a limited number of paid staff and unpaid affiliated experts (mostly academics), and five think tanks completely rely on volunteers.

These large differences in policy capacity were also noted by Pautz, who in his work on think tanks underlined that although they "want to change policy through intellectual argument rather than through behind the scenes lobbying", they are characterized by

\footnotetext{
6 These nine think tanks are: Grattan Institute, Lowy Institute, Institute of Public Affairs, Australian Strategic Policy Institute, Australia Institute, Sydney Institute, Centre for Independent Studies, Climate Institute and Committee for Economic Development of Australia.
} 
substantial differences in capacity, as "some carry out little research themselves and commission external experts to recycle existing research while others have considerable internal research capacities" (2010: 276). In a similar vein, 't Hart and Vromen characterize think tanks as "virtual organizations", as they have "a (very) small permanent staff which manages a sometimes extensive network of experts, financiers, partners and clients" (2008: 137; see also Marsh and Stone 2004: 25). Considering the limited staff of these organizations and their ascribed "virtual nature", it is rather surprising to note that of the 21 think tanks that completed our survey, 19 indicated to do at least $70 \%$ of their research activities in-house.

This result suggests closer scrutiny of the meaning of "research activities" to think tank staff. While our results confirm that think tanks consider research capacity and intellectual credibility as critical to their work, the small staff size of most think tanks and the overall low reliance on outsourcing raises questions as to what extent they have the capacity to engage in scientific activities, or engage in original research (see also Weaver 1989). One suspects that they may in practice limit themselves to policy monitoring and liaising with academics and other providers of policy expertise. For instance, when comparing the analytical capacity of professional analysts and consultants working for the government with analysts located in NGOs, Howlett et al. found the latter group to be rather "underdeveloped" (2014). NGO analysts were generally less highly qualified and specialized, while their policy-related task was mostly focused on consulting stakeholders or decisionmakers, and identifying policy issues, rather than engaging in research and analysis or the provision of advice. In a similar vein, Stone has argued that think tanks are very effective organizations for translating dense ideas or abstract theory into "sound bites" for the media, blueprints for decision-makers and understandable pamphlets and publications for the educated public (2007: 272), or as Craft and Howlett indicated, translating distant research results into useable forms of knowledge (2012), in this way providing policy advice of a substantive rather than procedural nature (the latter which might be more typical of expertise provided by academics).

\section{Who's watching? The organizational autonomy of think tanks}

Along with other political organizations, such as political parties and interest groups, think tanks share the aim of shaping public policy. Still, a critical difference is that political parties usually have members. Likewise, interest groups often have an identifiable constituency, which can relate to a specific industry sector, profession or people who care about a particular cause. Hence, whereas interest groups tend to "speak on behalf of a particular constituency" and thus often emphasize the representative nature of their claims, think tanks aim to reach "as large a segment of the electorate as possible" (Abelson 2002: 11; cited in Pautz 2010; for research that draws more parallels between think tanks and interest groups, see Bertelli and Wenger 2009).

As a result, think tanks do not have a clear constituency (although in some cases they are considered part of a broader ideological network, see below), nor do they have internal mechanisms for democratic accountability. This high level of autonomy can be considered a crucial part of the identity of think tanks. Their integrity seems based on a belief that claims of independence (safeguarded by not being financially dependent on a single funding source, see Pautz 2010), and their lack of (structural) affiliations with other political organizations or individuals, should assure the public of the impartial or independent nature of their research. Rather than engaging in this particular debate (for an excellent and balanced discussion, see Campbell and Pedersen 2014: 223-228; for a more 
critical evaluation, see Shaw et al. 2015), we aim to highlight the lack of organizational constraints on the policy agenda of think tanks. While membership dynamics are not applicable to think tanks, financial resource dependencies might have a strong impact. Yet, when asked which factors shape the prioritization of specific issues, $<25 \%$ of the surveyed think tanks agreed with the statement that an issue is prioritized if "it is among the stated preferences of large donor or institutional contributors" (see Table 3 in the next section, where we address issue prioritization by think tanks in more depth). Considering this apparent lack of checks and balances, think tanks appear to have considerable room to manoeuvre when they translate their mission into political action. As few actors seem to be closely watching, they might have luxuries that political parties and interest groups do not afford. They are, for instance, not bound by constituency concerns and also seem less reliant on tactical access to policymakers. As a result, they can more easily formulate policy proposals that ignore policy legacies or party political constraints, or make use of strategic silence when policy issues pop up for which they have not yet determined a clear policy position. ${ }^{7}$

By considering the policy agenda of these organizations, that is, the policy domains and issues that these organizations prioritize, we can address their substantive policy interests in more detail (Halpin 2015). If we examine the policy interests formulated by think tanks in their mission, we observe a mixture of very broad-based and encompassing organizations whose agenda can be described as "public policy" oriented, as well as more focussed think tanks. The first group generally does not include a clear substantive policy focus in its organizational mission. Instead, they claim to focus on "reducing political, social and economic inequality", aim to "build a new vision for Australia based on fairness, prosperity, community and social justice", or simply define their mission as "research that matters, shape policy debate and outcomes by using research". By contrast, the second group highlights specific policy domains, such as environment, science or international affairs. An overview of the policy focus of the 59 Australian think tanks (that we identified through a media search and consulting academic articles) is included in Table 2. We see that 16 think tanks in the total population have what we consider a "general" policy agenda, which involves a wide range of issues related to multiple policy domains. These are the organizations with the maximum scope of policy interest and flexibility in respect of their policy agenda, a feature that might enable them to cross-policy domains and ensure the policy integration that is considered imperative for effectively addressing systemic issues (see Peters 2015: 266).

We acknowledge that identifying a policy domain tells us little about the specific policy preferences of these organizations, or their ideological persuasion. In principle, one distinctive element of think tanks is their capacity to work above the partisan divisions in the political system. That is, they are expected to bridge the divide between the major parties, and develop debates on issues that do not descend into party political squabbles. When asked to define the essence of a think tank, the independent and non-partisan nature of these organizations was emphasized by several respondents. With the exception of party think tanks such as Chifley (Labor Party) and Menzies Research Centre (Liberal Party), no think tanks indicated that they have formal ties with particular parties. Nor did they generally report any structural relations with organized interests, except for formal ties with labor unions in a very few cases. On the other hand, various scholars have highlighted the ideological character of some think tanks, as some of them strongly identify with a

\footnotetext{
7 In such a position, interest groups or parties would typically be expected to feel pressure from their supporters/members to act (or be seen to act).
} 
Table 2 Policy agenda $(n=59)$

\begin{tabular}{lrlr}
\hline Domain & $N$ & Domain & $N$ \\
\hline Public Policy & 16 & Feminism & 1 \\
International Affairs & 12 & Health & 1 \\
Regional Australia & 3 & Labour & 1 \\
Education & 3 & libertarian & 1 \\
Climate & 3 & Migration & 1 \\
Economy & 3 & North Australia & 1 \\
Industrial Relations & 2 & Religion & 1 \\
Environment & 2 & Science & 1 \\
Agriculture & 1 & Sydney & 1 \\
Aviation & 1 & Tourism & 1 \\
Animal Rights & 1 & Transport and Logistics & 1 \\
Communication & 1 & & \\
\hline
\end{tabular}

conservative or progressive worldview (e.g. Stone 1991; Rich 2004; Vromen and Hurley 2015; Shaw et al. 2015).

If research is being outsourced, universities and individual academics are most often named as key partners $(n=9)$, while some think tanks also mention consultancy companies $(n=5)$. The core network of these think tanks thus mainly seems to consist of academics, rather than other political organizations. Why do these think tanks predominantly appear an academic affair? Some have suggested that the value of academics as source of information, inspiration and critique might form an explanation, while their involvement also renders think tank output more legitimate and credible (Pautz 2014: 5). Moreover, while relations with academics can be justified on grounds of their scientific, non-partisan knowhow, formal ties with political parties and organized interest are likely to threaten the image of a think tank as an independent, non-partisan organization.

This finding challenges earlier arguments that think tanks function as "interstitial points at which powerful networks of interest intersect" (Smith and Marden 2008). While it might be accurate that high-profile think tanks (in particular conservative ones) gather membership, financial support and intellectual stimuli from a similar pool of resources, these powerful and expansive networks seem foremost of an informal nature and surely not typical of the average think tank. Furthermore, while there are some think tanks that strongly define themselves on ideological grounds, such as progressive, conservative or libertarian, many of them appear to shy away from such labels, and mainly stress a particular issue or policy focus in their mission (see also Vromen and Hurley 2015: 171). Consequently, there seems much room for interpretation and strategic manoeuvring when think tanks determine their policy agenda (even if they depart from a particular ideological viewpoint); an assumption that will be addressed more closely in the next section of this article.

\section{Pioneering policy entrepreneurs with a long-term orientation}

Like most political organizations, think tanks must make decisions as to which specific policy issues they will engage with (Halpin 2015, see also Donas et al. 2014). Due to limited resources and attention, they cannot pursue all policy issues that possibly are of interest to them. Whereas we addressed the policy agenda of think tanks in the previous section, here we focus on the mechanisms that shape which specific policy issues these organizations will prioritize. To acquire more insights about these mechanisms, we asked 
think tanks to what extent different considerations shaped their decisions to put a particular issue front and centre. The results of this question are displayed in Table 3.

We already addressed that most think tanks have either a generalist or a more specific sectoral focus - e.g. environment, regional affairs, or international affairs - and thus, we would expect this to shape immediate choices (see Table 2). Indeed, as expected, the mission of the organization proved to be an important anchor. Respectively, 17 and 16 of the 21 respondents agreed with the statement that they address an issue that is mentioned as a priority in their mission, or that is in the interests of the people or institutions that they represent (even though their constituency is often rather unclear, see our discussion above). While it makes sense that, for instance, organizations focused on climate change prioritize environmental issues, within this policy space they still need to work out which precise set of issues to highlight. In that regard, it is notable that all but one of the respondents agreed with the statement that they prioritize an issue when "the issue is one that other likeminded organizations are not dealing with, and that this organization believes needs attention". While we should be careful not to over interpret this, as about $50 \%$ indicated that they focus on issues that other organizations are also dealing with, it shows that the predominant-almost universal-driver of issue selection for think tanks is moving into free policy space.

This result aligns with the view that think tanks generally seek to push innovative ideas (which might not be realistic or feasible given the prevailing political conditions). It thus highlights a possible critical contribution of think tanks to public policy, as it suggests that they have the capacity (or at least the aspiration) to put over- or under-looked issues on the political agenda (which is considered a very difficult task, even for the most experienced and professionalized advocacy groups). Furthermore, what stands out in these results is the lack of attention to realpolitik in deciding on what to work on. For instance, we might have expected think tanks to focus on the art of the possible, and thus prioritise issues that are moving, or that correlate with punctuations in the political process (e.g. crisis). In this view, one would expect their activities and policy focus to be much more aligned with the current political agenda. However, we observe almost the opposite. Only, respectively, 7 and 6 think tanks indicated to mostly prioritize issues on which "the likelihood of victory is high", or on which they have "allies within government".

The characterization of think tanks as proactive policy pioneers with a forward-looking orientation is further supported by the reported balance between the long-term and shortterm focus of think tanks. When asked the question to what extent they focus organizational activities and resources on "long-standing issues that consistently receive their attention" versus "issues that attracted attention after 'popping up' unexpectedly", all but three think tank indicated to focus at least $75 \%$ of their activities on more long-term matters (average $=80$ ). While we do not have data to hand, our expectations would be that this is likely to be the reverse for interest groups, who generally face stronger incentives to select "moving" issues, or topics on which "success" is more likely. Hence, think tanks can be considered providers of what Craft and Howlett label as "evidence-based policymaking advice" (2012), or what Prasser (2006) has termed "cold" or "rational" advice. Whereas the latter is considered information based, proactive and systemic, "hot" or "political" advice is seen as more opinion and single issue based, and likely to be reactive or crisis driven. ${ }^{8}$ Furthermore, while the first is generally based on information and

\footnotetext{
8 Prasser (2006).
} 
Table 3 Issue prioritization (\% think tanks agreeing with statement; $n=21$ )

\begin{tabular}{|c|c|c|c|}
\hline We prioritize an issue when... & $\%$ & We prioritize an issue when... & $\%$ \\
\hline $\begin{array}{l}\text { 1. ...the issue is one that other like-minded } \\
\text { organizations are not dealing with, and this } \\
\text { organization believes needs attention }\end{array}$ & 95 & $\begin{array}{l}10 . \ldots \text { the issue is one that is being addressed } \\
\text { by this organization's organizational } \\
\text { opponents, and thus needs to be addressed so } \\
\text { its point of view is heard }\end{array}$ & 43 \\
\hline $\begin{array}{l}\text { 2. ... the issue is explicitly mentioned as a } \\
\text { priority in our organization's mission } \\
\text { statement, policy statement, or similar } \\
\text { document }\end{array}$ & 81 & $\begin{array}{l}11 . \ldots \text { the issue is among the stated preferences } \\
\text { of our members }\end{array}$ & 43 \\
\hline $\begin{array}{l}\text { 3. ... the issue is in the interests of the people } \\
\text { or institutions this organization represents }\end{array}$ & 76 & $\begin{array}{l}\text { 12. ...the issue is currently on the } \\
\text { governmental agenda (i.e. it is being given } \\
\text { considerable attention by the government) }\end{array}$ & 38 \\
\hline $\begin{array}{l}\text { 4. ...the issue is currently of interest to the } \\
\text { leaders of this organization }\end{array}$ & 76 & $\begin{array}{l}\text { 13. ...the issue is currently on the public } \\
\text { agenda (i.e. it is being given considerable } \\
\text { attention by the public at large) }\end{array}$ & 38 \\
\hline $\begin{array}{l}\text { 5. ... our financial resources allow us } \\
\text { adequately to address the issue }\end{array}$ & 71 & $\begin{array}{l}\text { 14. ...the likelihood of victory on the issue is } \\
\text { high }\end{array}$ & 33 \\
\hline $\begin{array}{l}\text { 6. ...the issue is one that can be effectively } \\
\text { addressed given existing in-house staff } \\
\text { experience. }\end{array}$ & 67 & $\begin{array}{l}\text { 15. ... we have allies within government to } \\
\text { help this organization "win" on the issue }\end{array}$ & 29 \\
\hline $\begin{array}{l}\text { 7. ...the issue is one that other like-minded } \\
\text { organizations are dealing with, and that this } \\
\text { organization believes can be addressed more } \\
\text { effectively with further attention }\end{array}$ & 52 & $\begin{array}{l}\text { 16. ... the issue is among the stated preferences } \\
\text { of large donor contributors (i.e. members } \\
\text { who contribute in excess of membership } \\
\text { dues) }\end{array}$ & 24 \\
\hline $\begin{array}{l}\text { 8. ...the issue is currently on the media agenda } \\
\text { (i.e. it is being given considerable attention } \\
\text { by the media) }\end{array}$ & 48 & $\begin{array}{l}\text { 17. ... we have opponents within government } \\
\text { who work against us on the issue }\end{array}$ & 24 \\
\hline $\begin{array}{l}\text { 9. ... a recent event such as a crisis or a } \\
\text { disaster highlights the importance of the issue }\end{array}$ & 43 & $\begin{array}{l}\text { 18. ...the issue is among the stated preferences } \\
\text { of some of our institutional Contributors } \\
\text { (e.g. private foundations) }\end{array}$ & 19 \\
\hline
\end{tabular}

research that is of an independent and strategic nature, and seeks the optimal answer to policy questions, the latter is conceived as more opinion based and biased, and a result of pragmatism and consensus.

\section{Synthesis: organizational features and policy advice}

In the previous section, we analysed three features that we consider important for organizations to possess in order to contribute to strategic policy-making. Here, we provide a synthesis of our results and reconnect our work to previous research on policy advisory systems. There appear to be some features that are more or less common characteristics of all the think tanks we examined. First, our results demonstrate that there is very little variation with respect to having a long-term orientation. All but a few think tanks tend to strongly prioritize issues on which they have a long-standing interest (in contrast to issues that are currently on the governmental or public agenda). In addition, almost all think tanks indicated that they work on policy matters that get little or no attention from other political actors. On this empirical basis, we consider these features to be more or less common characteristics of think tanks. However, we do observe considerable variation among think 
Table 4 Typology of think tanks

\begin{tabular}{lll}
\hline & High autonomy & Low autonomy \\
\hline High research capacity & Strategic think tank & Advocacy think tank \\
Low research capacity & Amateur think tank & Sole-trader think tank \\
\hline
\end{tabular}

tanks with respect to both research capacity (and the extent to which this is prioritized) and their level of organizational autonomy. While we highlighted the considerable differences in resources (and the extent to which a "reputation for intellectual quality and integrity" is ranked as a priority), it is worth highlighting the variance in terms of the assessed impact of institutional donors. Asked to what extent they are likely to prioritize an issue that is among the stated preferences of large donor or institutional contributors, respectively, five and four think tanks did indicate to agree with this statement. We think these two variables offer us a way to distinguish among think tanks (Table 4).

Taking these findings into account, a typology can be developed that revisits previous categorizations of think tanks (e.g. Weaver 1989; Stone 1991; for recent discussions, see 't Hart and Vromen 2008; Pautz 2011, 2014), yet considers research capacity and organizational autonomy as the prime dimensions. Those groups with both high autonomy and research capacity are referred to as strategic think tanks on the basis that they are particularly well equipped to make a substantial contribution to strategic policy-making. The polar opposite are sole-trader think tanks, so-called because they tend to be "one-person and a web-site" kind of operations. Those organizations with low autonomy, but high capacity, are referred to as advocacy (or partisan) think tanks, as they tend to push specific agendas of their constituency, much as interest groups are assumed to do. Finally, we refer to those organizations with low capacity, but high autonomy, as amateur think tanks. These often have plenty of latitude to push work in whatever direction they wish, but often lack the professionalism and resources (in terms of money and time) to make a bigger policy impact. We believe that this typology can be linked to the role think tanks can play in the policy process, as well as the type of policy advice that they are most likely to provide. For instance, Rich (2001) argues that whereas partisan think tanks are more likely to offer political support, more neutral ones appear better placed to offer policy guidance. The key differentiating factor here seems to be a difference in organizational autonomy. Likewise, the level of autonomy and research capacity is likely to shape the particular kind of advice a think tank can provide. While even a "sole trader" might be able to offer "crisis and firefighting advice" (short-term reactive and substantive), such an organization seems much less well placed to offer "evidence-based" expertise (long-term anticipatory and substantive). ${ }^{9}$

\section{Conclusion and discussion}

In this article, we assessed the potential of think tanks to contribute to strategic policymaking, focusing on what we argue are three critical dimensions: research capacity, organizational autonomy and a long-term orientation. While our results provide strong

\footnotetext{
9 To evaluate the value of such a typology, one obviously needs both more fine-grained measures of organizational autonomy and research capacity, as well as (ideally) some comparative benchmarks that go beyond the Australian case.
} 
evidence for considering think tanks as proactive, anticipatory policy actors who are keen to move into new policy spaces, our findings on their organizational autonomy and research capacity are less conclusive. As regards their policy agenda, we noted that think tanks certainly face fewer internal and external constraints compared to interest groups and political parties. In addition, several think tanks have a rather broad and generalist mission, which leaves them not only considerable room for selecting policy issues, but also enables them to cross-sectoral silos and put forward integrative policy solutions. Overall, many think tanks can be characterized as "policy entrepreneurs": organizations who develop innovative and creative policy solutions, generally act in both a strategic and opportunistic way, and are assumed to be more powerful in a fragmented and clustered policy space (Christopoulos and Ingold 2015). This puts them in contrast to so-called policy brokers, who are much more focused on mediating between coalitions, finding feasible policy compromises and ensuring political stability. A further examination of these different roles could be a productive avenue for further research, as well as a closer examination of the different uses of policy evidence (e.g. to adjust policy output, as a source of legitimacy or to substantiate existing preferences, e.g. Boswell 2008; Daviter 2015; Schrefler 2010).

Finally, what are the implications of our findings for the type of policy advice that think tanks can provide, and more generally their possible role in policy advisory systems? Our work suggests rather than viewing particular organizational types (such as think tanks or advocacy groups) as possessing unique capabilities, we should refocus our attention on whether political organizations possess certain organizational features (see also Halpin 2014: chapter 10). As regards the organizational features that we considered indicative of the strategic policy-making capacity of a think tank, we noticed considerable variation among the think tanks that completed our survey. We contend that an organization's capacity to provide a certain type of advice can be connected to particular organizational characteristics, for instance a certain level of organizational autonomy, or an organization's ability to move into new policy spaces. As Rich argues, "one cannot understand experts or their expertise without an acknowledgement and appreciation as well of the organizations in which they are embedded" (2001: 599). This view resonates with the recent work of Craft and Howlett, which highlights that while think tanks are likely to be well placed to provide long-term and policy substance focused advice, they do not expect all think tanks to be equally well equipped to play this particular role.

Acknowledgments Previous versions of this article were presented at the International Conference in Interpretive Policy Analysis, 8-10 July 2015; and the Australian Political Studies Association Annual Conference, 28-30 September 2015. We would like to thank the participants in those panels for their helpful comments and suggestions. The research presented in this article has been supported by the Australian Research Council (ARC) Discovery Scheme (DP140104097). We would like to thank the interviewees for their time in answering our questions. We would also like to thank Dr. She Hawke for her assistance in conducting these telephone interviews. Last but not least we thank the anonymous referees and the journal editor for their critical yet constructive comments which have improved the article considerably.

\section{Appendix}

See Table 5. 
Table 5 Overview of Australian think tanks, year of establishment $(n=59)$

\begin{tabular}{|c|c|c|c|}
\hline Name & Birth & Name & Birth \\
\hline $\begin{array}{l}\text { Australian Institute for International } \\
\text { Affairs }\end{array}$ & 1924 & Kokoda Foundation & 2004 \\
\hline Australia Institute of Policy \& Science & 1932 & Voiceless & 2004 \\
\hline Institute of Public Affairs & 1943 & Australian Centre for Health Research & 2005 \\
\hline Australian Fabian Society & 1947 & Australian Environment Foundation & 2005 \\
\hline $\begin{array}{l}\text { Committee for Economic Development of } \\
\text { Australia }\end{array}$ & 1960 & Australian Institute of Employment Rights & 2005 \\
\hline Australian Defence Association & 1975 & Eidos Institute & 2005 \\
\hline Centre for Independent Studies & 1976 & Network Insight Institute & 2005 \\
\hline Evatt Foundation & 1979 & Society for Knowledge Economics & 2005 \\
\hline HR Nicholls Society & 1986 & Network Insight Institute & 2005 \\
\hline Sydney Institute & 1989 & World Growth & 2005 \\
\hline CAPA Centre for Aviation & 1990 & Beyond Zero Emissions & 2006 \\
\hline Foundation for Development Cooperation & 1990 & Centre for Policy Development & 2007 \\
\hline Women's Economic Think Tank & 1992 & Per Capita & 2007 \\
\hline Australia Institute & 1994 & Grattan Institute & 2008 \\
\hline Menzies Research Centre (Libs) & 1994 & Green Institute (Greens) & 2008 \\
\hline Institute for Private Enterprise & 1996 & Education Standards Institute & 2008 \\
\hline Mannkal Foundation & 1997 & Left Right Think Tank & 2008 \\
\hline $\begin{array}{l}\text { Sustainable Economic Growth for } \\
\text { Regional Australia }\end{array}$ & 1997 & Institute for Economics and Peace & 2009 \\
\hline Australian Libertarian Society & 2000 & Williams Foundation & 2009 \\
\hline Chifley Research Centre (ALP) & 2000 & $\begin{array}{l}\text { Australians for Northern Development and } \\
\text { Economic Vision }\end{array}$ & 2010 \\
\hline Future Directions International & 2000 & Indonesia Institute & 2010 \\
\hline Transport and Logistics Centre & 2000 & IdeasLAB & 2012 \\
\hline Australia21 & 2001 & McKell Institute & 2012 \\
\hline Australian Strategic Policy Institute & 2001 & Migration Council Australia & 2012 \\
\hline Committee for Sydney & 2001 & Regional Australia Institute & 2012 \\
\hline Page Research Centre (Nats) & 2002 & Tourism Think Tank & 2012 \\
\hline $\begin{array}{l}\text { Wentworth Group of Concerned } \\
\text { Scientists }\end{array}$ & 2002 & Ethos Environment & 2012 \\
\hline Australian Farm Institute & 2003 & Australian Climate Council & 2013 \\
\hline Lowy Institute for International Policy & 2003 & Learning First & 2014 \\
\hline Air Power Australia & 2004 & & \\
\hline
\end{tabular}

\section{References}

Abelson, D. E. (2002). Do think tanks matter? Assessing the impact of public policy institutes. Ithaca, NY: McGill-Queen's University Press.

Baumgartner, F. R., \& Jones, B. D. (1993). Agendas and instability in American Politics. Chicago: The University of Chicago Press.

Berkhout, J. (2013). Why interest organizations do what they do: Assessing the explanatory potential of 'exchange' approaches. Interest Groups and Advocacy, 22(2), 227-250. 
Bertelli, A. M., \& Wenger, J. B. (2009). Demanding information: Think tanks and the US Congress. British Journal of Political Science, 39, 225-242.

Boswell, C. (2008). The political functions of expert knowledge: Knowledge and legitimation in European Union immigration policy. Journal of European Public Policy, 15(4), 471-488.

Bouwen, P. (2002). Corporate lobbying in the European Union: The logic of access. Journal of European Public Policy, 9(3), 365-390.

Burstein, P. (2003). The impact of public opinion on public policy: A review and an agenda. Political Research Quarterly, 56(1), 29-40.

Campbell, J. L., \& Pedersen, O. K. (2014). The national origins of policy ideas: Knowledge regimes in the United States, France, Germany, and Denmark. Princeton: Princeton University Press.

Christopoulos, D., \& Ingold, K. (2015). Exceptional or just well connected? Political entrepreneurs and brokers in policy making. European Political Science Review, 7(3), 475-498.

Craft, J., \& Howlett, M. (2012). Policy formulation, governance shifts and policy influence: Location and content in policy advisory systems. Journal of Public Policy, 32(02), 79-98.

Craft, J., \& Wilder, M. (2015). Catching a second wave: Context and compatibility in advisory system dynamics. Policy Studies Journal, doi:10.1111/psj.12133.

Daviter, F. (2015). The political use of knowledge in the policy process. Policy Sciences, 48(4), 491-505.

della Porta, D. (2013). Can democracy be saved: Participation, deliberation and social movements. Cambridge: Polity Press.

Donas, T., Fraussen, B., \& Beyers, J. (2014). It's not all about the money: Explaining varying policy portfolios of regional representations in Brussels. Interest Groups and Advocacy, 3(1), 79-98.

Drutman, L. (2015). The business of America is lobbying: How corporations became politicized and politics became more corporate. Oxford: Oxford University Press.

Fraussen, B., Pattyn, V., \& Lawarée, J. (2016). Thinking in splendid isolation? The organization and policy engagement of think tanks in Belgium. In M. Brans \& D. Aubin (Eds.), Policy analysis in Belgium. Bristol: Policy Press.

Gray, V., \& Lowery, D. (1996). The population ecology of interest representation: Lobbying communities in the American States. Ann Arbor: University of Michigan Press.

Halligan, J. (1995). Policy advice and the public sector. In G. B. Peters \& D. T. Savoie (Eds.), Governance in a changing environment (pp. 138-172). Montreal: McGill-Queen's University Press.

Halpin, D. (2014). The organization of political interest groups. Designing advocacy. New York: Routledge.

Halpin, D. (2015). Interest group policy agendas. In A. Cigler, B. Loomis, \& A. Nownes (Eds.), Interest group politics (9th ed.). Washington: CQ Press.

Halpin, D., MacLeod, I., \& McLaverty, P. (2012). Committee hearings of the Scottish parliament: Evidence giving and policy learning. The Journal of Legislative Studies, 18(1), 1-20.

Hill, C. J., \& Lynn, L. E. (2005). Is hierarchical governance in decline? Evidence from empirical research. Journal of Public Administration Research and Theory, 15(2), 173-195.

Howlett, M., Ramesh, M., \& Wu, X. (2015). Understanding the persistence of policy failures: The role of politics, governance and uncertainty. Public Policy and Administration, 30(3-4), 209-220.

Howlett, M., Tan, S. L., Migone, A., Wellstead, A., \& Evans, B. (2014). The distribution of analytical techniques in policy advisory systems: Policy formulation and the tools of policy appraisal. Public Policy and Administration, 29(4), 271-291.

Jones, B. D., \& Baumgartner, F. R. (2005). The politics of attention: How government prioritizes problems. Chicago: University of Chicago Press.

Jordan, G. (2007). Policy without learning: Double devolution and abuse of the deliberative idea. Public Policy and Administration, 22(1), 48-73.

Jordan, A. G., \& Greenan, J. (2012). The changing contours of British representation: Pluralism in practice. In D. Halpin \& A. G. Jordan (Eds.), The scale of interest organization in democratic politics: Data and research methods (pp. 67-98). New York: Palgrave Macmillan.

Maloney, W., Jordan, G., \& McLaughlin, M. (1994). Interest groups and public policy: The insider/outsider model revisited. Journal of Public Policy, 14(1), 17-38.

Marsh, I. (1994). The development and impact of Australia's “Think Tanks". Australian Journal of Management, 19(2), 177-200.

Marsh, I. (1995). Beyond the two party system. Cambridge: Cambridge University Press.

Marsh, I., \& Miller, R. (2012). Democratic decline, democratic renewal: Britain, Australia, New Zealand. Cambridge: Cambridge University Press.

Marsh, I., \& Stone, D. (2004). Australian think tanks. In D. Stone \& A. Denham (Eds.), Think tank traditions: Policy research and the politics of ideas (pp. 247-263). Manchester: Manchester University Press. 
Marsh, D., Toke, D., Belfrage, C., Tepe, D., \& McGough, S. (2009). Policy networks and the distinction between insider and outsider groups: The case of the countryside alliance. Public Administration, 87(3), 621-638.

May, P. J., \& Jochim, A. E. (2013). Policy regime perspectives: Policies, politics, and governing. Policy Studies Journal, 41(3), 426-452.

May, P. J., Koski, C., \& Stramp, N. (2014). Issue expertise in policymaking. Journal of Public Policy, doi:10.1017/S0143814X14000233.

McConnell, A. (2008). Governing after crisis: The politics of investigation, accountability and learning. Cambridge: Cambridge University Press.

McGann, J. G. (2015). 2014 Global Go to Think Tank Index Report Think tanks and civil societies program. University of Pennsylvania.

Milward, H. B., \& Provan, K. G. (2000). Governing the hollow state. Journal of Public Administration Research and Theory, 10(2), 359-380.

Pautz, H. (2010). Think tanks in the United Kingdom and Germany: Actors in the modernisation of social democracy. British Journal of Politics \& International Relations, 12(2), 274-294.

Pautz, H. (2011). Revisiting the think-tank phenomenon. Public Policy and Administration, 26(4), 419-435.

Pautz, H. (2013). The think tanks behind 'Cameronism'. British Journal of Politics \& International Relations, 15(3), 362-377.

Pautz, H. (2014). British think-tanks and their collaborative and communicative networks. Politics, 34(4), $345-361$.

Peters, B. G. (2015). State failure, governance failure and policy failure: Exploring the linkages. Public Policy and Administration, 30(3-4), 261-276.

Pierson, P. (2004). Politics in time: History, institutions and social analysis. Princeton: Princeton University Press.

Prasser, S. (2006). Providing Advice to Government. Papers on Parliament. Canberra: Senate of Australia. http://www.aph.gov.au/About_Parliament/Senate/Powers_practice_n_procedures/pops/ /link.aspx?_ $\mathrm{id}=11 \mathrm{AB} 0553 \mathrm{BB} 894 \mathrm{CD} 4 \mathrm{A00F5E67C6A0B649 \& \_ z=z.}$

Rasmussen, A., Carroll, B., \& Lowery, D. (2013). Representatives of the public? Public opinion and interest group activity. European Journal of Political Research, 53(2), 250-268.

Rich, A. (2001). The politics of expertise in congress and the news media. Social Science Quarterly, 82(3), 583-601.

Rich, A. (2004). Think tanks, public policy, and the politics of expertise. Cambridge: Cambridge University Press.

Rich, A. O., \& Weaver, R. K. (1998). Advocate and analysist: Think tanks and the politicization of expertise. In A. J. Cigler \& B. A. Loomis (Eds.), Interest group politics. Washington, CQ: CQ Press.

Schlozman, K. L., \& Tierney, J. T. (1986). Organized interests and American democracy. New York: Harper \& Row.

Schmitter, P. C., \& Streeck, W. (1999). The organization of business interests. Studying the associative action of business in advanced industrial societies. MPifG discussion paper. Max-Planck-Institut für Gesellschaftsforschung, Köln.

Schrefler, L. (2010). The usage of scientific knowledge by independent regulatory agencies. Governance-an International Journal of Policy Administration and Institutions, 23(2), 309-330.

Shaw, S. E., Russel, J., Parsons, W., \& Greenhalgh, T. (2015). The view from nowhere? How think tanks work to shape health policy. Critical Policy Studies, 9(1), 58-77.

Smith, M. A. (2000). American business and political power: Public opinion, elections, and democracy. Chicago: University of Chicago Press.

Smith, M., \& Marden, P. (2008). Conservative think tanks and public politics. Australian Journal of Political Science, 43(4), 699-717.

Stone, D. (1991). Old guard versus new partisans: Think tanks in transition. Australian Journal of Political Science, 26(2), 197-215.

Stone, D. (2000). Introduction to the symposium: The changing think tank landscape. Global Society, 14(2), $149-152$.

Stone, D. (2007). Recycling bins, garbage cans or think tanks? Three myths regarding policy analysis institutes. Public Administration, 85(2), 259-278.

Stone, D., \& Denham, A. (2004). Think tank traditions: Policy research and the politics of ideas. New York: Manchester University Press.

't Hart, P., \& Vromen, A. (2008). A new era for think tanks in public policy? International trends, Australian realities. Australian Journal of Public Administration, 67(2), 135-148.

van der Steen, M. A., \& van Twist, M. J. W. (2013). Foresight and long-term policy-making: An analysis of anticipatory boundary work in policy organizations in The Netherlands. Futures, 54, 33-42. 
Vromen, A., \& Hurley, P. (2015). Consultants, think tanks and public policy. In B. Head \& K. Crowley (Eds.), Policy analysis in Australia (pp. 167-183). Bristol: Policy Press.

Walker, J. L. (1991). Mobilizing interest groups in America. Ann Arbor: University of Michigan Press.

Weaver, R. K. (1989). The changing world of think tanks. PS: Political Science \& Politics, 22(03), 563-578.

Yankelovich, D. (1991). Coming to public judgement. Syracuse, NY: Syracuse University Press. 